\title{
Melatonin Reduces Inflammatory Injury Through Inhibiting NF- $\kappa$ B Activation in Rats With Colitis
}

\author{
Jun-Hua Li, Jie-Ping Yu, Hong-Gang Yu, Xi-Ming Xu, Liang-Liang Yu, Jin Liu, and He-Sheng Luo \\ Department of Gastroenterology, Renmin Hospital of Wuhan University, Hubei Province, Wuhan 430060, China
}

Received 10 May 2005; Accepted 31 May 2005

\begin{abstract}
Proinflammatory mediators are important in the pathogenesis of IBD, which are regulated by activation of NF- $\kappa$ B. The aim of this study was to investigate whether melatonin reduces inflammatory injury and inhibits proinflammatory molecule and NF- $\kappa \mathrm{B}$ in rats with colitis. Rat colitis model was established by TNBS enema. NF- $\kappa$ B p65, TNF- $\alpha$, ICAM-1, and I $\kappa$ B $\alpha$ in colon tissue were examined by immunohistochemistry, EMSA, RT-PCR, and Western blot analysis. Expression of proinflammatory molecule and activation of NF- $\kappa \mathrm{B}$ were upregulated and $\mathrm{I} \kappa \mathrm{B}$ level decreased in rats with colitis. Melatonin reduces colonic inflammatory injury through downregulating proinflammatory molecule mediated by NF- $\kappa \mathrm{B}$ inhibition and blockade of I $\kappa \mathrm{B} \alpha$ degradation.
\end{abstract}

\section{INTRODUCTION}

Ulcerative colitis (UC), a major inflammatory bowel disease (IBD), is a chronic intestinal inflammatory disease which afflicts more and more people in China [1]. Although exact etiology and pathogenesis remain obscure, there is substantial evidence that proinflammatory cytokines and adhesion molecules including tumor necrosis factor- $\alpha$ (TNF- $\alpha)$ and intercellular adhesion molecule1 (ICAM-1) exhibit a key role in the inflammatory process $[2,3,4]$. And many studies have shown increased production of TNF- $\alpha$ and ICAM-1 in intertinal mucosa, serum, lamina propria mononuclear cells (LPMC), and peripheral blood mononuclear cells (PBMC) in patients with UC, which is thought to be an important factor in the pathophysiology of intestinal inflammation in UC $[5,6,7]$. At present, medical treatment of UC relies mainly on traditional drugs: aminosalicylates, corticosteroids, and immunosuppressants. These drugs including glucocorticoids and aminosalicylates reduce inflammatory injury and attenuate the expression of some proinflammatory molecules but their side effects and systemic action are so hard that they disturb the life quality of patients severely, particularly during long-term treatment. And so, it is very important to find an optimal therapy for UC.

Recent studies have unequivocally shown that the expressions of TNF- $\alpha$ and ICAM-1 are regulated by the

Correspondence and reprint requests to Hong-Gang Yu, Department of Gastroenterology, Renmin Hospital of Wuhan University, Hubei Province, Wuhan 430060, China; yuhonggang@yahoo.com transcription factor nuclear factor kappa $\mathrm{B}(\mathrm{NF}-\kappa \mathrm{B})$; NF$\kappa \mathrm{B}$ play a central role in immune and inflammatory responses and may be a good target for therapy $[8,9]$. NF$\kappa \mathrm{B}$ is mostly composed of RelA (p65) and NF- $\kappa \mathrm{B} 1(\mathrm{p} 50)$; these NF- $\kappa \mathrm{B}$ dimers are kept in an inactive cytoplasmic complex by inhibitory proteins, the inhibitor protein kappa $\mathrm{B}(\mathrm{I} \kappa \mathrm{B})$ family, in resting cells. NF- $\kappa \mathrm{B}$ can be activated within minutes by a variety of stimuli, including inflammatory molecules such as TNF- $\alpha$ and IL-1, growth factors, bacterial lipopolysaccharide (LPS), and oxidative stress, which induce site-specific phosphorylation of $\mathrm{I} \kappa \mathrm{B}$ and consecutive rapid dissociation of the complex accompanied by proteolytic degradation of $\mathrm{I} \kappa \mathrm{B}$. The released NF- $\kappa \mathrm{B}$ proteins subsequently transmigrate from cytoplasm into the nucleus where they can induce gene transcription by binding to specific promoter elements $[10,11,12]$. Activated NF- $\kappa \mathrm{B}$ has been demonstrated in colonic epithelial cells and macrophages of patients with IBD $[13,14]$, and also NF- $\kappa$ B p 65 antisense oligonucleotide treatment was reported to have much benefit in experimental colitis, although toxicity effects must be carefully analyzed $[15,16]$. The above data predict that NF- $\kappa \mathrm{B}$ is a new and more effective therapy target.

Melatonin, mainly produced in the pineal gland, play an important physiological role in immunoregulation, inflammatory responses, and oxidative stress. Gastrointestinal tract is a rich source of extrapineal melatonin. And melatonin release may have a direct effect on many gastrointestinal tissues but may also well influence the digestive tract indirectly [17]. Some previous data have shown that melatonin can alleviate colonic injury in experimental colitis induced by both dextran sulfate sodium and dinitrobenzene sulfonic acid in rats 
$[18,19]$, but the mechanism of action of exogenous melatonin against inflammatory injury is not apparent. These therapeutic effects of melatonin rely at least partially on immunomodulatory function, for example, inhibiting the action of macrophages in inflammatory tissues [20]. Meanwhile, other studies have demonstrated that melatonin exerts an antioxidant and scavenger effect on free radicals to reduce the severity of colitis [18].

In this study we investigated if melatonin reduces inflammation in 2,4,6-trinitrobenzene sulfonic acid (TNBS)-induced colitis through an inhibitory effect on proinflammatory molecule expression and the transcription factor NF- $\kappa \mathrm{B}$.

\section{MATERIALS AND METHODS}

\section{Animals}

Healthy adult Sprague-Dawlay (SD) rats of both sexes, weighing $250 \pm 30 \mathrm{~g}$, were obtained from the Experimental Animal Center of Wuhan University (Wuhan, China). Animals were housed under specific pathogen-free conditions and allowed access to standard rat chow and water. Before the experiments, they were acclimatized to the surroundings for one week. The study protocol was in accordance with the guidelines for animal research and was approved by the Ethical and Research Committee of the hospital.

\section{Experimental protocol and colitis induction}

Rat model of colitis induced with 2,4,6-trinitrobenzene sulfonic acid (TNBS, Sigma Co, Shanghai, China) enema was described in the literature [21]. The experimental animals were randomly divided into six groups of 10 each: normal group, model group, 5aminosalicylic acid(5-ASA) group, and melatonin treatment group that were treated with saline, TNBS/40\% ethanol(150 mg/kg), 5-aminosalicylic acid(100 mg/kg), and melatonin (Sigma Co) at doses of 2.5, 5.0, $10.0 \mathrm{mg} / \mathrm{kg}$ enema, respectively (once a day, from the 24 hours after colitis was established to the end of experiment). At the end of a 4-week period, the animals were sacrificed and the colon samples were collected.

Colon tissues were fixed in 4\% paraformaldehyde, dehydrated, and paraffin embedded. Four-micrometer sections were cut transversely and stained with hemotoxylin and eosin. Colon macroscopic and histological damage indices were evaluated by an independent pathologist blindly as reported previously [20, 22]. At the same time, colon samples from the same sites were also obtained and frozen immediately in liquid nitrogen for subsequent determination.

\section{Immunohistochemistry detection}

Sections of colon tissues were kept in an oven at $4^{\circ} \mathrm{C}$ overnight and were deparaffinized in xylene and rehydrated. Endogenous peroxidase activity was blocked with $1 \%$ hydrogen peroxide for 20 minutes. And microwave oven-based antigen retrieval was performed. Slides were probed with either anti-RelA (1:50, rat monoclonal, Santa Cruz Biotechnology), anti-TNF- $\alpha$ (1:100, rat polyclonal, Santa Cruz Biotechnology), or anti-ICAM-1 (1:100, rat monoclonal, Santa Cruz Biotechnology). Sections were washed three times with PBS for 10 minutes each and incubated with biotin-labeled antirat IgG for 1 hour at room temperature, respectively. After three washes with PBS for 10 minutes each, the slides were developed in $0.05 \%$ freshly prepared diaminobenzedine solution for several minutes and then counterstained with hematoxylin. Incubation with PBS instead of the primary antibody served as a negative control. In specimens containing positive cells, the positive cells were counted in ten randomly selected fields under high-power microscope (400-fold magnification) for each sample, and the average was expressed as the density of positive cells.

\section{EMSA analysis}

Nuclear protein extracts were prepared as described previously [13]. Fresh colon samples were homogenized in $400 \mu \mathrm{L}$ of hypotonic lysis buffer A ( $10 \mathrm{mmol} / \mathrm{L}$ HEPES $\mathrm{pH} 7.9,10 \mathrm{mmol} / \mathrm{L} \mathrm{KCl}, 0.1 \mathrm{mmol} / \mathrm{L}$ EDTA, $0.1 \mathrm{mmol} / \mathrm{L}$ EGTA, $1 \mathrm{mmol} / \mathrm{L}$ DTT, and $1 \mathrm{mmol} / \mathrm{L}$ PMSF). Homogenized tissues were incubated on ice for 5 minutes, NP40 was added to a final concentration of $5 \mathrm{~g} / \mathrm{L}$, and samples were vigorously mixed and centrifuged. The cytoplasmic proteins were removed and the pellet nuclei were resuspended in $50 \mu \mathrm{L}$ buffer C $(20 \mathrm{mmol} / \mathrm{L}$ HEPES $\mathrm{pH} \quad 7.9,0.4 \mathrm{~mol} / \mathrm{L} \mathrm{NaCl}, 1 \mathrm{mmol} / \mathrm{L}$ EDTA, $1 \mathrm{mmol} / \mathrm{L}$ EGTA, $1 \mathrm{mmol} / \mathrm{L}$ DTT, and $1 \mathrm{mmol} / \mathrm{L} \mathrm{PMSF).} \mathrm{After}$ 30 -minute agitation at $4^{\circ} \mathrm{C}$, the samples were centrifuged and supernatants, containing nuclear proteins, were transferred to a fresh vial. The protein concentrations of nuclear extracts were determined by Bradford protein assay. Nuclear protein extracts of colon tissues were analyzed by EMSA for NF- $\kappa \mathrm{B}$ nuclear translocation as previously described $[23,24]$. EMSA binding reaction mixture contained $8 \mu \mathrm{g}$ protein of nuclear extracts, $2 \mu \mathrm{g}$ of poly (deoxyinosinic-deoxycytidylic acid) (Sigma Co), and $\left[{ }^{32} \mathrm{P}\right]$-labeled double-stranded oligonucleotide containing the binding motif of NF- $\kappa \mathrm{B}$ probe $(4000 \mathrm{cpm})$ in binding buffer $(10 \mathrm{mmol} / \mathrm{L}$ HEPES $\mathrm{pH}$ 7.9, $50 \mathrm{mmol} / \mathrm{L} \mathrm{NaCl}, 1 \mathrm{mmol} / \mathrm{L}$ EDTA, $1 \mathrm{mmol} / \mathrm{L}$ DTT, $100 \mathrm{~mL} / \mathrm{L}$ glycerol, and $0.2 \mathrm{~g} / \mathrm{L}$ albumin). The sequence of the double-stranded oligomer used for EMSA was $5^{\prime}$ AGTTGAGGGGACTTTCCCAGGC-3' . The reaction was incubated for 30 minutes at room temperature before separation on a $50 \mathrm{~g} / \mathrm{L}$ acrylamide gel, followed by autoradiography. For supershift experiments, $2 \mu \mathrm{g}$ of rat monoclonal antibodies against the p65 subunit (Santa Cruz Biotechnology) of NF- $\kappa \mathrm{B}$ was incubated with the nuclear extracts 10 minutes before the addition of the $\left[{ }^{32} \mathrm{P}\right]$ labeled probe and then analyzed as described. 


\section{Western blot analysis}

Colon samples were snap frozen in liquid nitrogen at the time of removal and later mechanically homogenized $(20 \% \mathrm{w} / \mathrm{v})$ in lysis buffer consisting of $20 \mathrm{mM}$ HEPES, pH 7.4, $0.1 \mathrm{mM}$ EDTA, $12.5 \mathrm{mM} \mathrm{MgCl}_{2}, 150 \mathrm{mM}$ $\mathrm{NaCl}, 0.1 \%$ Nonidet P40, $0.2 \mathrm{mM}$ phenylmethylsulfonyl fluoride, $1 \mathrm{mM}$ dithiothreitol, and $1 \mu \mathrm{g} / \mathrm{mL}$ concentration of each of pepstatin, leupeptin, and aprotinin. The homogenates were transferred to Eppendorf tubes, sonicated for 10 seconds and then centrifuged at $14000 \mathrm{rpm}$ for 10 minutes. Protein concentrations of samples were assessed using the method of Bradford protein assay, and all samples were adjusted to an equal protein content before analysis. Samples ( $20 \mu \mathrm{g}$ of total protein) were separated on a $12 \%$ denaturing polyacrylamide gel. Separated proteins were transferred to a nitrocellulose membrane ( $20 \mathrm{~V}, 90$ minutes; transfer buffer $25 \mathrm{mM}$ Tris, $190 \mathrm{mM}$ glycine, $20 \%$ methanol, $0.5 \%$ sodium dodecyl sulfate) by an electroblotter (Bio-ram). The membrane was placed into blocking buffer ( $5 \%$ nonfat milk in $20 \mathrm{mM}$ Tris/ $\mathrm{HCl}, \mathrm{pH} 7.6,140 \mathrm{mM} \mathrm{NaCl}, 0.5 \%$ Tween 20) for one hour at room temperature. Blocking buffer was decanted and the membrane was incubated with the primary antibody anti- $\mathrm{I} \kappa \mathrm{B} \alpha$ (1:500 diluted in blocking buffer, Sigma Co) on a shaker at $4^{\circ} \mathrm{C}$ overnight. After being washed (in $20 \mathrm{mM}$ Tris $/ \mathrm{HCl}, \mathrm{pH} 7.6,140 \mathrm{mM}$ $\mathrm{NaCl}, 0.1 \%$ Tween 20), the membrane was incubated with a peroxidase-conjugated secondary antibody, which was diluted in 5\% nonfat milk in wash buffer (one hour; room temperature; gentle shaking). Being washed, the membrane was exposed to sensitive film several minutes after incubation in Western blotting luminol reagent (Cell Signal Corp). The bands were quantified by densitometry.

\section{$R T-P C R$}

The mRNA expressions of TNF- $\alpha$ and ICAM-1 were assessed using RT-PCR standardized by coamplifying housekeeping gene $\beta$-actin, which served as an internal control. Total RNA from colon tissues was isolated using trizol reagent (Sigma Co) by the single-step method and was reversely transcribed into cDNA. The resulting cDNA was used as a template for subsequent polymerase chain reaction (PCR). The rat-specific primers (sense and antisense primers) for TNF- $\alpha$, ICAM- 1 , and $\beta$-actin were $5^{\prime}$-CATGATCCGAGATGTGGAACTGGC- $3^{\prime}$ and $5^{\prime}$-CTGGCTCAGCCACTCCAGC-3' (TNF- $\left.\alpha, 315 \mathrm{bp}\right)$; $5^{\prime}$-AGGTATCCATCCATCCCACA- $3^{\prime}$ and $5^{\prime}$-AGTGTCTCATTCCCACGGA-3' (ICAM-1388 bp); 5'-ATGGATGACGATATCGCTG-3' $3^{\prime}$ and $5^{\prime}$-ATGAGGTAGTCTGTCAGGT-3' ( $\beta$-actin, 568 bp), respectively. Amplification was performed in 30 cycles with initial incubation at $95^{\circ} \mathrm{C}$ for 3 minutes and final extension at $72^{\circ} \mathrm{C}$ for 7 minutes, each cycle of which consisted of denaturation for 30 seconds at $95^{\circ} \mathrm{C}$, annealing for 45 seconds at $55^{\circ} \mathrm{C}$, and extension for 1 minute at $72^{\circ} \mathrm{C}$. PCR products were separated on $15 \mathrm{~g} / \mathrm{L}$ agarose gels containing $0.5 \mathrm{~g} / \mathrm{L}$ of ethidium bromide and visualized by UV transillumination. HPIAS-1000 software analysis system was used to determine the relative absorbance of mRNA expression.

\section{Myeloperoxidase assay}

Colon samples were weighed and homogenized in a solution prepared from the assay kit (Nanjing Jiancheng Bioengineering Co Ltd, China), and homogenates of $5 \%$ were obtained and used for MPO assay. MPO can catalyze the redox reaction of $\mathrm{H}_{2} \mathrm{O}_{2}$ and 3,3,5,5tetramethylbenzidine and produce yellow-colored compounds through whose absorbance at $460 \mathrm{~nm}$ MPO activity was calculated and expressed as $\mathrm{U} / \mathrm{g}$ wet tissue. One unit of MPO activity was defined as the quantity of enzyme that degraded $1 \mu \mathrm{mol} \mathrm{H}_{2} \mathrm{O}_{2}$ at $37^{\circ} \mathrm{C}$ per g wet tissue.

\section{Statistical analysis}

All statistical analyses were performed with SPSS10.0 statistical package from Microsoft Windows. Student $t$ test and one-way analysis of variance (ANOVA) were used to compare continuous variables among groups. Data were finally expressed as mean \pm standard error of the mean. $P$ values less than .05 were considered statistically significant.

\section{RESULTS}

\section{Effect of melatonin on inflammatory injury of colitis}

Pronounced pathological changes of colonic mucosa similar to that in human IBD were observed in rats with colitis induced by TNBS enema. Most animals inflicted with TNBS enema had disease limited to the rectum and rectosigmiod, some had disease extending beyond the sigmoid or had a total colitis. The mucosa was hyperemic, edematous, and granular, and some small punctate ulcers were visible. There was an inflammatory infiltrate of neutrophils, lymphocytes, and macrophages. Eosinophils and mast cells were also present in increased numbers. The colon mucosal macroscopic and histological injury indices, and MPO activity were significantly increased in these experimental animals compared with normal controls. Administration with melatonin enema at different dosages could effectively reduce the severity of mucosa injury and alleviate the colitis symptoms. And the parameter of mucosa injury was significantly decreased in a dosedependent manner in rats treated by melatonin compared with that in model control animals $(P<.01$, Table 1$)$.

\section{Effect of melatonin on proinflammatory molecules and NF- $\kappa$ B RelA protein production}

The protein expressions of TNF- $\alpha$ and t ICAM- 1 in colon tissues were significantly increased in rats inflicted with TNBS enema compared with those of the normal controls. The positive cells of TNF- $\alpha$ and ICAM-1 were 
TABLE 1. Effects of melatonin and 5-ASA on the macroscopical and histological damage indices and MPO activity in rats $(\bar{x} \pm s n=10)$. a denotes that $P<.01$ versus the model group.

\begin{tabular}{lcccc}
\hline Group & Doses $\left(\mathrm{mg} \cdot \mathrm{kg}^{-1}\right)$ & Macroscopic index & Histological index & MPO activity $\left(\mathrm{U}^{-g^{-1}}\right)$ \\
\hline Normal & - & $0.75 \pm 0.71^{\mathrm{a}}$ & $1.1 \pm 0.83^{\mathrm{a}}$ & $25 \pm 19^{\mathrm{a}}$ \\
Model & - & $6.25 \pm 1.39$ & $6.24 \pm 1.04$ & $207 \pm 26$ \\
5-ASA & 100 & $1.60 \pm 0.53^{\mathrm{a}}$ & $1.35 \pm 0.47^{\mathrm{a}}$ & $126 \pm 15^{\mathrm{a}}$ \\
Melatonin & 2.5 & $5.70 \pm 1.21$ & $5.85 \pm 0.76$ & $190 \pm 20$ \\
Melatonin & 5.0 & $3.00 \pm 0.76^{\mathrm{a}}$ & $3.88 \pm 0.99^{\mathrm{a}}$ & $155 \pm 19^{\mathrm{a}}$ \\
Melatonin & 10.0 & $1.63 \pm 0.74^{\mathrm{a}}$ & $1.38 \pm 0.52^{\mathrm{a}}$ & $129 \pm 31^{\mathrm{a}}$ \\
\hline
\end{tabular}

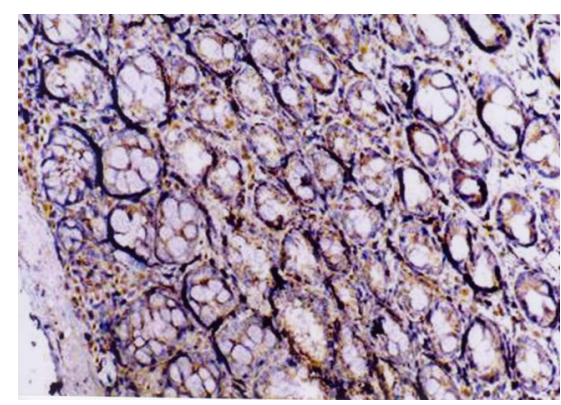

(a)

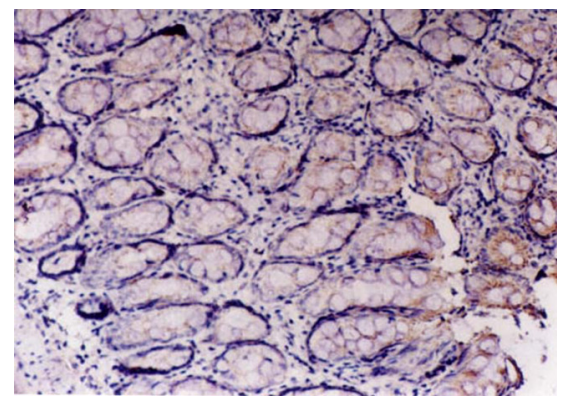

(b)

FIGURE 1. Immunohistochemical staining of RelA in colon tissues of (a) model rats and (b) rats with melatonin treatment $\left(10 \mathrm{mg} \cdot \mathrm{kg}^{-1}\right) . \mathrm{SP} \times 200$. RelA protein is mainly expressed in the nucleus and cytoplasmic accumulation of RelA is also detected. RelA expression decreases dramatically in melatonin group.

with brown-yellow cytoplasma or nuclear membrane and predominantly located within the mucosa and mucosa lamina propria; positive staining of RelA was mainly observed in the cytoplasm, and nuclear staining for RelA was also detected (Figures 1, 2, and 3). RelA, TNF- $\alpha$, and ICAM-1 protein expression decreased dose dependently in rats with melatonin treatment. Effect of $10 \mathrm{mg} / \mathrm{kg}$ melatonin was similar to that of 5-aminosalicylic acid $(100 \mathrm{mg} / \mathrm{kg})$. And similar results were obtained with NF$\kappa \mathrm{B}$ protein expression (Table 2 ).

\section{Effect of melatonin on proinflammatory molecules $m R$ RA expression}

RT-PCR analysis revealed increased mRNA levels for TNF- $\alpha$ and ICAM- 1 in colon tissues of the model group; melatonin could reduce molecule mRNA expression dose dependently; 5-aminosalicylic acid reduced the expression of molecule mRNAs, too. These results are in accord with immunohistochemical analysis of molecule expression (Figure 4).

\section{Effect of melatonin on NF- $\kappa$ B activation}

NF- $\kappa$ B-DNA binding activity was analyzed by EMSA analysis. Increased NF- $\kappa \mathrm{B}$ DNA binding activity and the RelA/NF- $\kappa$ B complexes were detected in model animals. Supershift analysis with antibodies specific for RelA (p65) and a competitive study with a 50-fold excess of unlabeled oligonucleotide showed that the antibody specific for RelA which recognizes RelA/NF- $\kappa$ B heterodimer, unlabeled oligonucleotide diminished the intensity of RelA/NF- $\kappa$ B complexes and indicated that complex was the NF- $\kappa \mathrm{B}$ binding-specific band. And the NF- $\kappa \mathrm{B}-\mathrm{DNA}$ binding activity was inhibited dose dependently when animals were treated with melatonin and 5-aminosalicylic acid; the inhibition effect of melatonin was most obvious at a concentration of $10 \mathrm{mg} / \mathrm{kg}$ (Figure 5).

\section{Effect of melatonin on I $k B$ protein levels}

Western blot analysis of protein extracts of colon tissues showed that $\mathrm{I} \kappa \mathrm{B} \alpha$ expression was weak in samples from rats without treatment, while it was stronger in the rats with melatonin and 5-aminosalicylic acid treatment. But there was no significant difference in the extent of $\mathrm{I} \kappa \mathrm{B} \alpha$ expression in colon tissues of rats with melatonin treatment and normal controls (Figure 6).

\section{DISCUSSION}

The incidence and prevalence of IBD increase in China, and medical treatment of theirs is sometimes unsatisfactory at present. Our studies have demonstrated that melatonin given by intrarectal administration reduced rats colitis induced by TNBS and elucidated the molecule mechanism of melatonin inhibitory 
TABLE 2. Effects of melatonin and 5-ASA on protein expression of RelA, TNF- $\alpha$, and ICAM-1 in colon tissue $(\bar{x} \pm s n=10) .{ }^{\text {a denotes }}$ that $P<.01$ versus the model group.

\begin{tabular}{lcccc}
\hline Group & Doses $\left(\mathrm{mg}^{-k g^{-1}}\right)$ & RelA & TNF- $\alpha$ & ICAM-1 \\
\hline Normal & - & $9.10 \pm 0.76^{\mathrm{a}}$ & $16.03 \pm 6.21^{\mathrm{a}}$ & $13.41 \pm 4.91^{\mathrm{a}}$ \\
Model & - & $60.73 \pm 13.41$ & $84.09 \pm 14.52$ & $77.69 \pm 8.09$ \\
5-ASA & 100 & $15.27 \pm 7.25^{\mathrm{a}}$ & $19.95 \pm 7.43^{\mathrm{a}}$ & $20.35 \pm 8.62^{\mathrm{a}}$ \\
Melatonin & 2.5 & $52.24 \pm 10.86$ & $78.20 \pm 13.65$ & $71.63 \pm 10.34$ \\
Melatonin & 5.0 & $30.26 \pm 10.20^{\mathrm{a}}$ & $53.40 \pm 8.79^{\mathrm{a}}$ & $47.01 \pm 8.82^{\mathrm{a}}$ \\
Melatonin & 10.0 & $16.95 \pm 6.83^{\mathrm{a}}$ & $23.04 \pm 6.76^{\mathrm{a}}$ & $21.50 \pm 6.95^{\mathrm{a}}$ \\
\hline
\end{tabular}

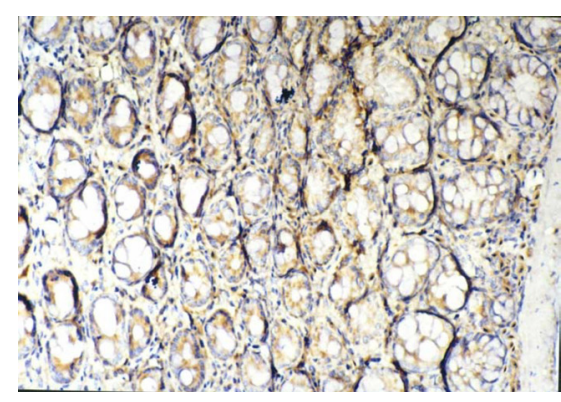

(a)

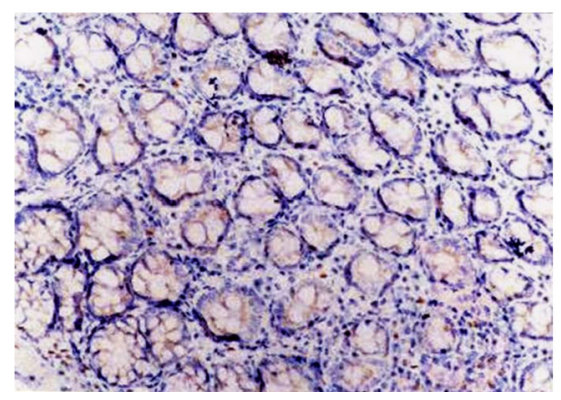

(b)

FIGURE 2. Immunohistochemical staining for TNF- $\alpha$ protein expression in (a) the model group and (b) melatonin group (10 mg. $\left.\mathrm{kg}^{-1}\right)$. $\mathrm{SP} \times 200$. The number of TNF- $\alpha$ immunoreactive positive cells in melatonin group is significantly less than that of model group.

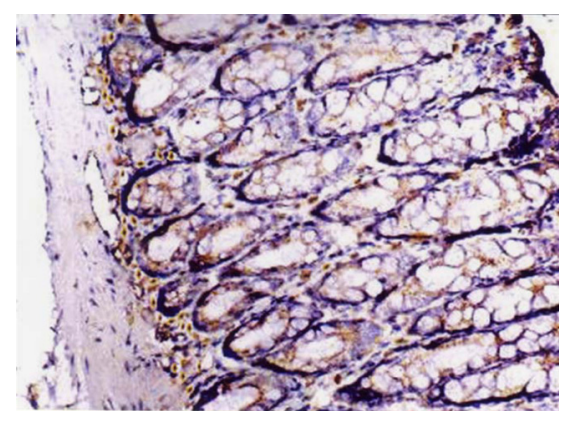

(a)

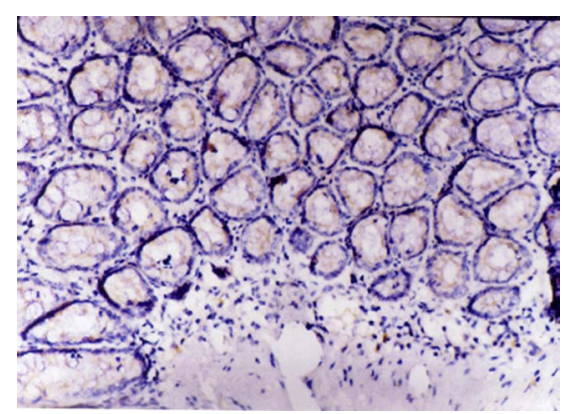

(b)

FIGURE 3. Immunohistochemical staining for ICAM-1 protein expression. $\mathrm{SP} \times 200$. Expression of ICAM-1 in (a) the normal group, (b) melatonin group $\left(10 \mathrm{mg} \cdot \mathrm{kg}^{-1}\right)$. The ICAM-1 expression was downregulated markedly in melatonin group.

inflammatory responses in TNBS-induced colitis by inhibition of NF- $\kappa$ B activation firstly.

Ulcerative colitis is characterized by chronic inflammation of colon of unknown etiology, and infiltration and persistence of inflammatory cells within tissues are hallmarks of inflammation $[25,26,27,28]$. Both TNF- $\alpha$ and ICAM-1 have been suggested to be important mediators involved in the initiation and perpetuation of intestinal inflammation in ulcerative colitis, and the activities of TNF- $\alpha$ and ICAM- 1 are often used as sensitive indicators for evaluating the colitis severity $[29,30]$. We confirmed that colon tissue obtained from rats with TNBS-induced colitis exhibited significantly more TNF- $\alpha$ and ICAM-1 expressions than normal controls, which supported the idea that proinflammatory molecules participate in the occurrence and development of ulcerative colitis. At the same time, we found that melatonin inhibited protein expression of TNF- $\alpha$ and ICAM- 1 dose dependently. In addition, our results showed that melatonin could attenuate the colitis symptoms such as rectal bleeding and occult 


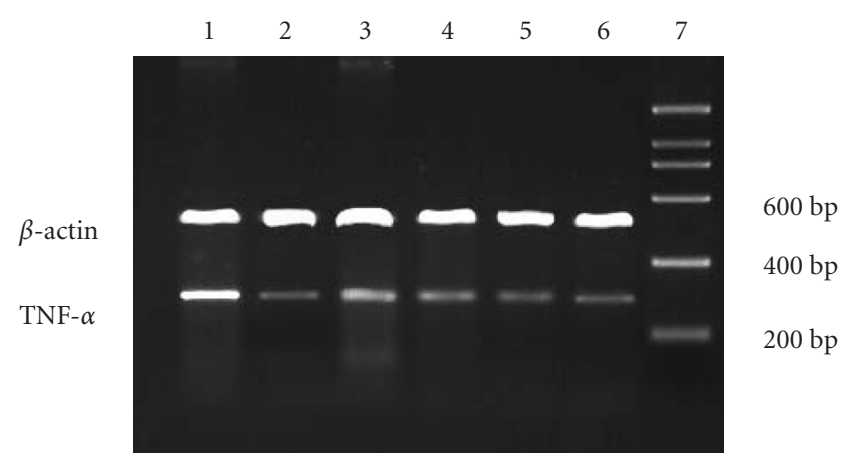

(a)

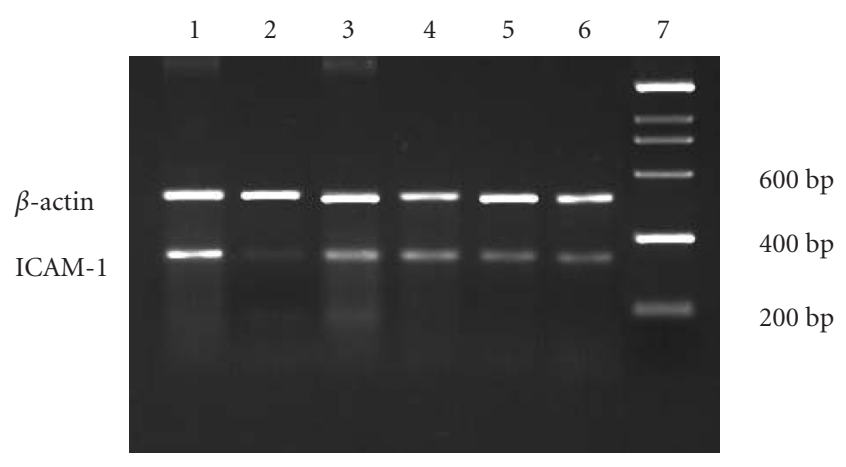

(b)

FIGURE 4. The mRNA expressions of (a) TNF- $\alpha$ and (b) ICAM-1 were assessed using RT-PCR standardized by coamplifying the housekeeping gene $\beta$-actin. Lanes 1-7: model, normal, melatonin (2.5, 5.0, $\left.10.0 \mathrm{mg} \cdot \mathrm{kg}^{-1}\right)$, 5-ASA, marker.

blood and reduce the frequency and severity of mucosa damage dramatically. These significant protective effects may be partly due to its effect on inhibition of expression of proinflammatory molecule including TNF- $\alpha$ and ICAM-1.

In order to elucidate the mechanism of action of melatonin on proinflammatory molecule, we investigated the mRNA expression of TNF- $\alpha$ and ICAM- 1 in colon tissues of rats and determined the influence of melatonin treatment on proinflammatory molecule mRNA production. We found that the mRNA expressions were in accord with the results of immunohistochemistry detection; RT-PCR analysis revealed increased mRNA levels for TNF- $\alpha$ and ICAM- 1 in colon tissues of the model group. Similarly, melatonin had a dose-dependent effect in decreasing mRNA expression of proinflammatory molecule. This prompted us to investigate the regulation of proinflammatory molecule gene transcription in the process of inflammatory responses. The important candidate is transcription factor NF- $\kappa \mathrm{B}$, which positively regulates the transcription of genes involved in immune and inflammatory responses.

Activation of NF- $\kappa$ B may be a pivotal event in proinflammatory signal transduction. Moreover, it has been shown that NF- $\kappa$ B activation is increased in the colonic mucosa of IBD patients $[13,14]$. In most resting cells, transcription factor members of the Rel-NF- $\kappa \mathrm{B}$ are bound to cytoplasmic inhibitory factors $I \kappa B s$ and are released on activation-induced degradation of their cytoplasmic inhibitors by the proteasome/ubiquitin complex $[31,32$, 33]. NF- $\kappa \mathrm{B}$ p65 hetero- or homodimers migrate to the nucleus and regulate transcriptional activity by binding to specific DNA sequences in promoter/enhancer regions of inflammation genes. Genes regulated by NF- $\kappa \mathrm{B}$ include those encoding IL-2, IL-6, IL-8, the IL-2 receptor, the IL12 P40 subunit, VCAM-1, ICAM-1, TNF- $\alpha$, and so forth $[8,9,31,32,33]$. And studies have also shown that the ICAM- 1 and TNF- $\alpha$ gene promoters have binding sites for NF- $\kappa$ B [34]; the heightened activation of NF- $\kappa$ B could be a major regulator of proinflammatory molecule secretion in IBD. We therefore investigated the effect of melatonin on transcription factor NF- $\kappa \mathrm{B}$ and our results have shown that melatonin inhibited nuclear translocation of $\mathrm{NF}-\kappa \mathrm{B}$ and mRNA expression controlled by it in rats with TNBS-induced colitis. Translocation into the nucleus and binding to target DNA sequences are important events for $\mathrm{NF}-\kappa \mathrm{B}$ to control transcription process, which relies on phosphorylation of $\mathrm{I} \kappa \mathrm{B}$, mediated by $\mathrm{I} \kappa \mathrm{B}$ kinases $(\mathrm{IKK}-\alpha$, $\beta$ ), followed by its degradation by the proteasome $[8,11]$. We further determine if melatonin interferes with $\mathrm{I} \kappa \mathrm{B}$ 


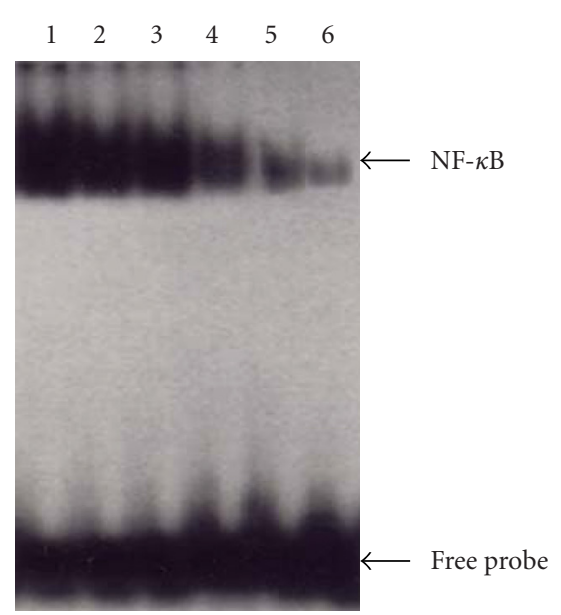

(a)

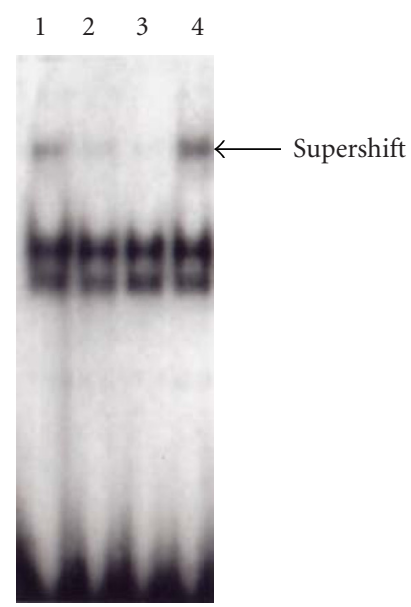

(b)

FIGURE 5. Electrophoretic mobility shift assay demonstrating nuclear translocation and DNA binding of NF- $\kappa$ B. (a) Lanes 16: model, melatonin $\left(2.5,5.0,10.0 \mathrm{mg} \cdot \mathrm{kg}^{-1}\right), 5$-ASA, normal. (b) Lanes 1-4: the model group, lanes 2-3: specific competitor (using excess of unlabeled oligonucleotide), lanes 1 and 4: supershift (addition of p65 antibodies to the nuclear extracts).

levels by Western bolt experiments. We found that protein concentration of $\mathrm{I} \kappa \mathrm{B} \alpha$ in rats treated with melatonin was higher compared with that in rats without treatment, which indicated that the inhibitory effect of melatonin on $\mathrm{NF}-\kappa \mathrm{B}$ activation was mediated by stabilization of $\mathrm{I} \kappa \mathrm{B} \alpha$ levels. We also found that $\mathrm{I} \kappa \mathrm{B} \alpha$ protein levels were not significantly different in colon tissues from rats with melatonin treatment and normal controls; this suggested that the effect of melatonin on $\mathrm{I} \kappa \mathrm{B} \alpha$ was probably mainly due to blocking its degradation. Taken together, these data obtained in this study provide evidence that melatonin downregulates inflammatory responses through inhibition of NF- $\kappa$ B.

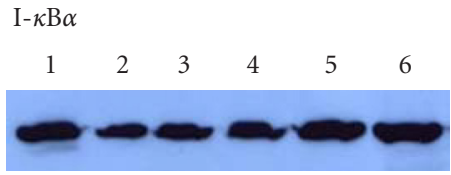

(a)

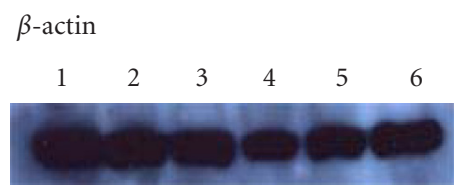

(b)

Figure 6. Western blotting showed levels of $\mathrm{I} \kappa \mathrm{B} \alpha$ in colon tissue of rats. Lanes 1-6: normal, model, melatonin (2.5, 5.0, $\left.10.0 \mathrm{mg} \cdot \mathrm{kg}^{-1}\right), 5$-ASA.

Previous studies have reported that glucocorticoids and salicylates inhibit the activation of $\mathrm{NF}-\kappa \mathrm{B} / \mathrm{Rel}$ through I $\kappa \mathrm{B}$ pathway; Weber et al [35] identified that sulfasalazine as a direct inhibitor of IKK- $\alpha$ and IKK$\beta$ blocks $\mathrm{I} \kappa \mathrm{B}$ degradation, then suppresses NF- $\kappa \mathrm{B}$ activation, which contributes to the antiinflammatory and immunosuppressive effects in IBD. Other investigators [36] demonstrated that increased $\mathrm{I} \kappa \mathrm{B} \alpha$ synthesis was present in glucocorticoid-treated patients with Crohn's disease and thus attenuated NF- $\kappa \mathrm{B}$ activation. In our study, melatonin may stabilize $\mathrm{I} \kappa \mathrm{B} \alpha$ against degradation, which is probably associated with $\mathrm{I} \kappa \mathrm{B} \alpha$ phosphorylation, so it will be important and interesting to define in which step melatonin affects $\mathrm{I} \kappa \mathrm{B}$ degradation process, and this will be a focus of future investigations.

To date, medical treatment of UC is limited to aminosalicylates, corticosteroids, and immunosuppressants. Although a variety of new therapies have been tested with variable success, none is ideal [37, 38, 39]. In our experimental model of colitis, melatonin treatment reduced colonic lesions and improved colitis symptoms through suppressing NF- $\kappa \mathrm{B}$ activation. In conclusion, because of its significant antiinflammatory properties, melatonin could be considered as the novel therapeutic alternative for the treatment of IBD. Further studies are needed to determine how melatonin combines with the established drugs such as sulfasalazine and corticosteroids in clinic.

\section{ACKNOWLEDGMENT}

The first author is employed in Xianning University now.

\section{REFERENCES}

[1] Jiang XL, Cui HF. An analysis of 10218 ulcerative colitis cases in China. World J Gastroenterol. 2002;8(1):158-161. 
[2] Lakatos L. Immunology of inflammatory bowel diseases. Acta Physiol Hung. 2000;87(4):355-372.

[3] Ogata H, Hibi T. Cytokine and anti-cytokine therapies for inflammatory bowel disease. Curr Pharm Des. 2003;9(14):1107-1113.

[4] Inoue S, Matsumoto T, Iida M, et al. Characterization of cytokine expression in the rectal mucosa of ulcerative colitis: correlation with disease activity. Am J Gastroenterol. 1999;94(9):2441-2446.

[5] Ishiguro Y. Mucosal proinflammatory cytokine production correlates with endoscopic activity of ulcerative colitis. J Gastroenterol. 1999;34(1):66-74.

[6] Fuss IJ. Cytokine network in inflammatory bowel disease. Curr Drug Targets Inflamm Allergy. 2003;2(2):101-112.

[7] Sans M, Panes J, Ardite E, et al. VCAM-1 and ICAM-1 mediate leukocyte-endothelial cell adhesion in rat experimental colitis. Gastroenterology. 1999;116(4):874-883.

[8] Baldwin AS Jr. Series introduction: the transcription factor NF- $\kappa \mathrm{B}$ and human disease. J Clin Invest. 2001;107(1):3-6.

[9] Jobin C, Sartor RB. NF-kappaB signaling proteins as therapeutic targets for inflammatory bowel diseases. Inflamm Bowel Dis. 2000;6(3):206-213.

[10] Glasgow JN, Wood T, Perez-Polo JR. Identification and characterization of nuclear factor kappaB binding sites in the murine bcl-x promoter. J Neurochem. 2000;75(4):1377-1389.

[11] Tak PP, Firestein GS. NF- $\kappa$ B: a key role in inflammatory diseases. J Clin Invest. 2001;107(1):7-11.

[12] Ghosh S, May MJ, Kopp EB. NF- $\kappa$ B and Rel proteins: evolutionarily conserved mediators of immune responses. Annu Rev Immunol. 1998;16:225-260.

[13] Schreiber S, Nikolaus S, Hampe J. Activation of nuclear factor kappa B inflammatory bowel disease. Gut. 1998;42(4):477-484.

[14] Rogler G, Brand K, Vogl D, et al. Nuclear factor kappa B is activated in macrophages and epithelial cells of inflamed intestinal mucosa. Gastroenterology. 1998;115(2):357-369.

[15] Neurath MF, Pettersson S, Meyer zum Buschenfelde $\mathrm{KH}$, Strober W. Local administration of antisense phosphorothioate oligonucleotides to the p65 subunit of NF-kappa B abrogates established experimental colitis in mice. Nat Med. 1996;2(9):9981004.

[16] Neurath MF, Pettersson S. Predominant role of NFkappa B p65 in the pathogenesis of chronic intestinal inflammation. Immunobiology. 1997;198(13):91-98.

[17] Bubenik GA. Gastrointestinal melatonin: localization, function, and clinical relevance. Dig Dis Sci. 2002;47(10):2336-2348.

[18] Pentney PT, Bubenik GA. Melatonin reduces the severity of dextran-induced colitis in mice. J Pineal Res. 1995;19(1):31-39.
[19] Cuzzocrea S, Mazzon E, Serraino I, et al. Melatonin reduces dinitrobenzene sulfonic acid-induced colitis. J Pineal Res. 2001;30(1):1-12.

[20] Mei Q, Yu JP, Xu JM, Wei W, Xiang L, Yue L. Melatonin reduces colon immunological injury in rats by regulating activity of macrophages. Acta Pharmacol Sin. 2002;23(10):882-886.

[21] Morris GP, Beck PL, Herridge MS, Depew WT, Szewczuk MR, Wallace JL. Hapten-induced model of chronic inflammation and ulceration in the rat colon. Gastroenterology. 1989;96(3):795-803.

[22] Dieleman LA, Palmen MJ, Akol H, et al. Chronic experimental colitis induced by dextran sulphate sodium (DSS) is characterized by Th1 and Th2 cytokines. Clin Exp Immunol. 1998;114(3):385-391.

[23] Wong BC, Jiang X, Fan XM, et al. Suppression of RelA/p65 nuclear translocation independent of $\mathrm{I} \kappa \mathrm{B}-$ $\alpha$ degradation by cyclooxygenase- 2 inhibitor in gastric cancer. Oncogene. 2003;22(8):1189-1197.

[24] Sosic D, Richardson JA, Yu K, Ornitz DM, Olson EN. Twist regulates cytokine gene expression through a negative feedback loop that represses NF- $\kappa \mathrm{B}$ activity. Cell. 2003;112(2):169-180.

[25] Monteleone G, MacDonald TT. Manipulation of cytokines in the management of patients with inflammatory bowel disease. Ann Med. 2000;32(8):552560.

[26] Brown KA, Back SJ, Ruchelli ED, et al. Lamina propria and circulating interleukin-6 in newly diagnosed pediatric inflammatory bowel disease patients. Am J Gastroenterol. 2002;97(10):26032608.

[27] Ito H, Hirotani T, Yamamoto M, Ogawa H, Kishimoto T. Anti-IL-6 receptor monoclonal antibody inhibits leukocyte recruitment and promotes T-cell apoptosis in a murine model of Crohn's disease. $J$ Gastroenterol. 2002;37(suppl 14):56-61.

[28] Sasaki M, Jordan P, Houghton J, et al. Transfection of IL-10 expression vectors into endothelial cultures attenuates $\alpha 4 \beta 7$-dependent lymphocyte adhesion mediated by MAdCAM-1. BMC Gastroenterol. 2003;3(1):3.

[29] Louis E. The immuno-inflammatory reaction in Crohn's disease and ulcerative colitis: characterisation, genetics and clinical application. Focus on TNF alpha. Acta Gastroenterol Belg. 2001;64(1):1-5.

[30] Woywodt A, Ludwig D, Neustock P, et al. Mucosal cytokine expression, cellular markers and adhesion molecules in inflammatory bowel disease. Eur J Gastroenterol Hepatol. 1999;11(3):267-276.

[31] Karin M, Ben-Neriah Y. Phosphorylation meets ubiquitination: the control of NF- $\kappa \mathrm{B}$ activity. Annu Rev Immunol. 2000;18:621-663.

[32] May MJ, Ghosh S. Signal transduction through NF$\kappa$ B. Immunol Today. 1998;19(2):80-88.

[33] Rothwarf DM, Zandi E, Natoli G, Karin M. IKKgamma is an essential regulatory subunit of the I 
kappa B kinase complex. Nature. 1998;395(6699): 297-300.

[34] Jobin C, Hellerbrand C, Licato LL, Brenner DA, Sartor RB. Mediation by NF- $\kappa$ B of cytokine induced expression of intercellular adhesion molecule 1(ICAM-1) in an intestinal epithelial cell line, a process blocked by proteasome inhibitors. Gut. 1998;42(6):779-787.

[35] Weber CK, Liptay S, Wirth T, Adler G, Schmid RM. Suppression of NF- $\kappa \mathrm{B}$ activity by sulfasalazine is mediated by direct inhibition of I $\kappa \mathrm{B}$ kinases $\alpha$ and $\beta$. Gastroenterology. 2000;119(5):1209-1218.

[36] Thiele K, Bierhaus A, Autschbach F, et al. Cell specific effects of glucocorticoid treatment on the NF$\kappa \mathrm{Bp} 65 / \mathrm{I} \kappa \mathrm{B} \alpha$ system in patients with Crohn's disease. Gut. 1999;45(5):693-704.

[37] Sands BE. Novel therapies for inflammatory bowel disease. Gastroenterol Clin North Am. 1999;28(2):323-351.

[38] Su CG, Wen X, Bailey ST, et al. A novel therapy for colitis utilizing PPAR-gamma ligands to inhibit the epithelial inflammatory response. J Clin Invest. 1999;104(4):383-389.

[39] Malhotra S, Bhasin D, Shafiq N, Pandhi P. Drug treatment of ulcerative colitis: unfractionated heparin, low molecular weight heparins and beyond. Expert Opin Pharmacother. 2004;5(2):329-334. 


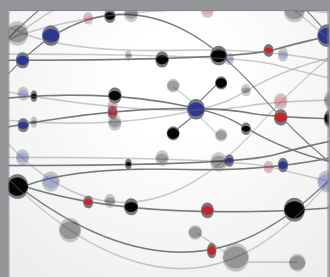

The Scientific World Journal
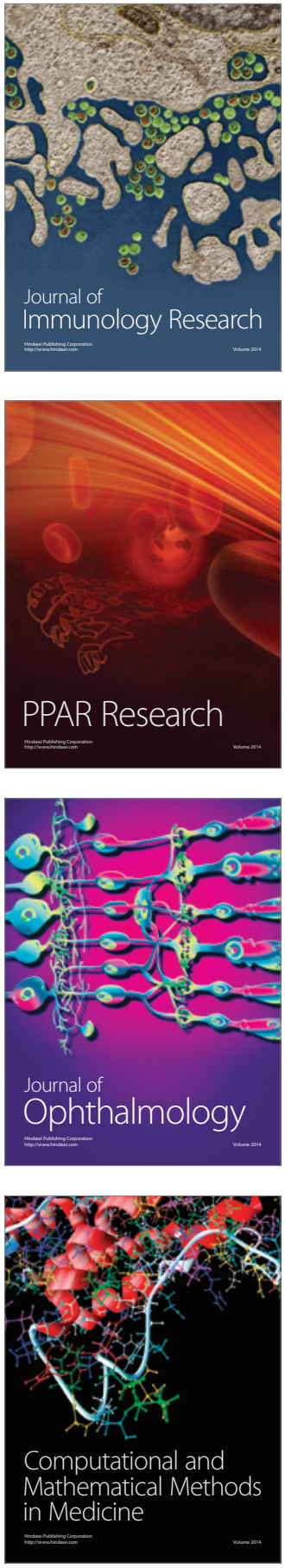

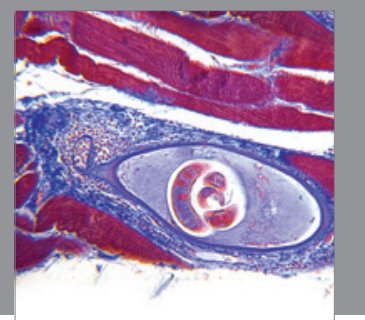

Gastroenterology

Research and Practice
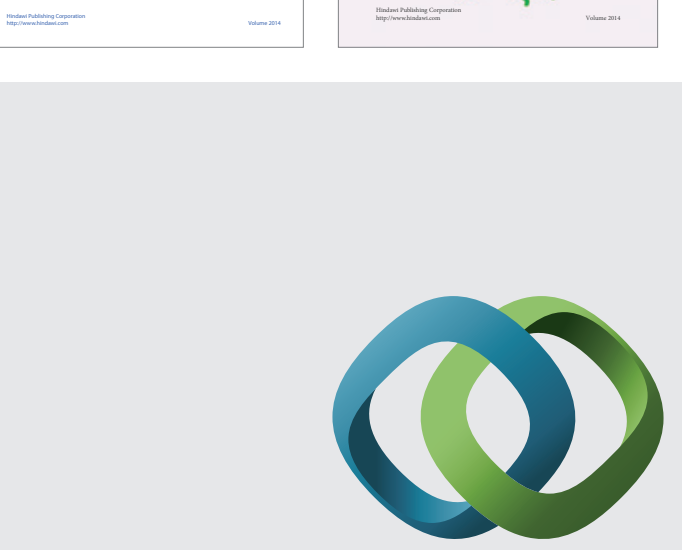

\section{Hindawi}

Submit your manuscripts at

http://www.hindawi.com
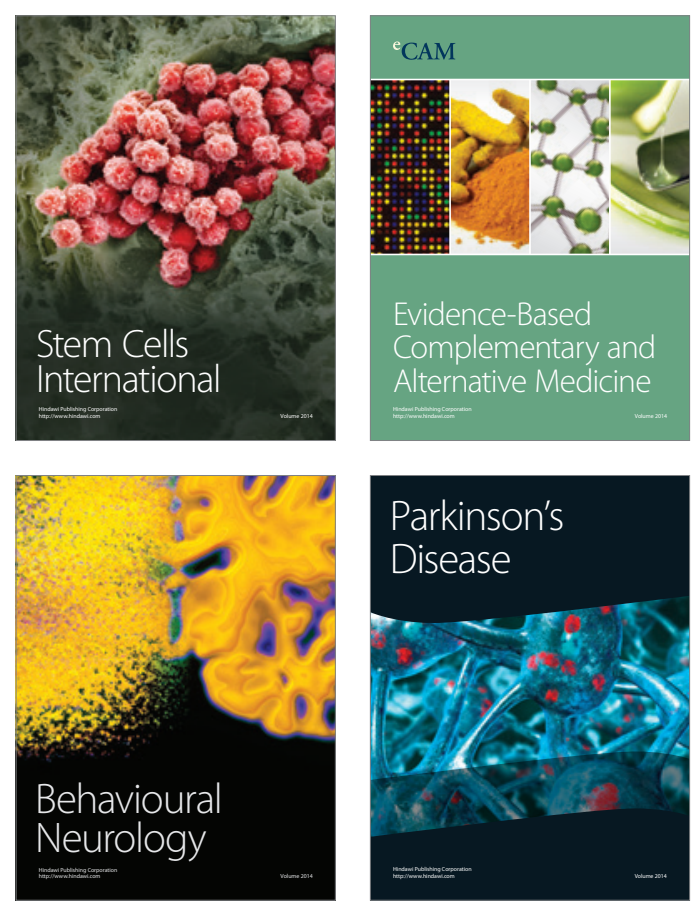

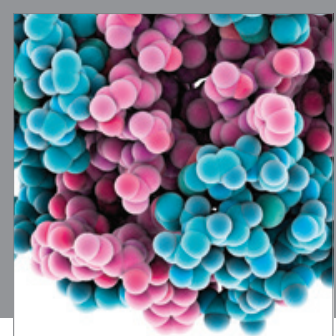

Journal of
Diabetes Research

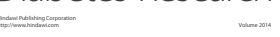

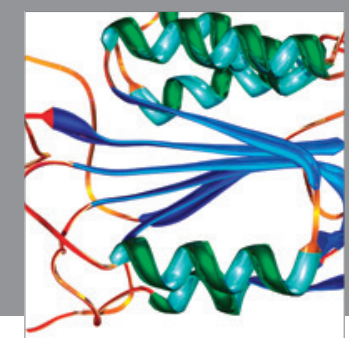

Disease Markers
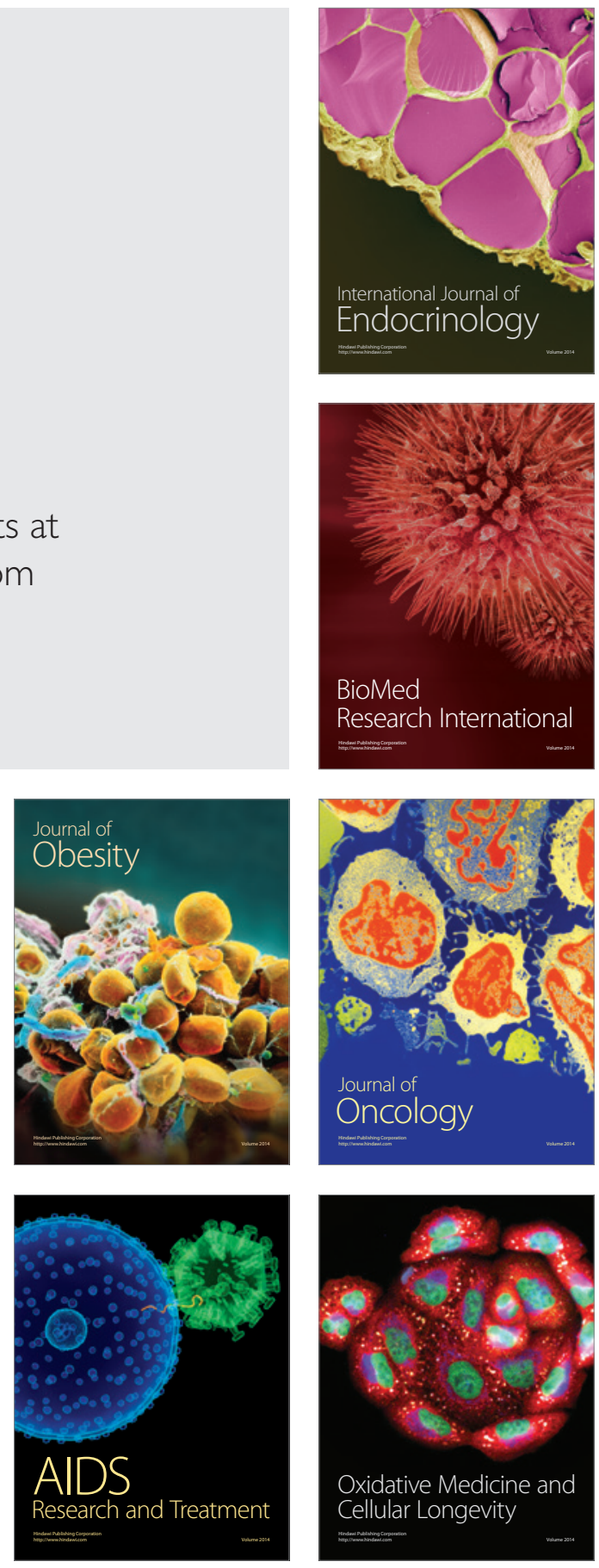